\title{
Creative Accounting: Nature, Incidence and Ethical Issues
}

Oriol Amat

Professor of Accounting, Universitat Pompeu Fabra, Barcelona

Catherine Gowthorpe

Research Fellow in Accounting, Oxford Brookes University

Keywords: Accounting ethics, creative accounting, earnings management, financial reporting.

Journal of Economic Literature classification: M41. 


\begin{abstract}
This paper explores the nature and incidence of creative accounting practices within the context of ethical considerations.. It explores several definitions of creative accounting and the potential and the range of reasons for a company's directors to engage in creative accounting. Later the paper considers the various ways in which creative accounting can be undertaken and summarizes some empirical research on the nature and incidence of creative accounting. The ethical dimension of creative accounting is discussed, drawing evidence from several empirical studies.

The paper concludes with the analysis of possible solutions for the creative accounting problem.
\end{abstract}




\section{Creative accounting: nature, incidence and ethical issues}

\section{Introduction}

According to agency theory 'the firm is a legal fiction which serves as a focus for a complex process in which the conflicting objectives of individuals... are brought into equilibrium within a framework of contractual relations.' (Jensen and Meckling, 1976). Within the agency framework, it is both logical and inescapable that management behaviour will be self-serving. Agency can, therefore, provide a solid framework for the understanding of creative accounting behaviour. However, it may provide an incomplete theoretical basis for explaining or predicting management behaviour; the ethical dimension of human behaviour may provide an important element missing from legalistic and adversarial agency relationships (Horrigan, 1987).

The informational perspective (Schipper, 1989) is a key element underpinning the study of the creative accounting phenomenon. A conflict is created by the information asymmetry that exists in complex corporate structures between a privileged management and a more remote body of stakeholders. Managers may choose to exploit their privileged position for private gain, by managing financial reporting disclosures in their own favour. The informational perspective assumes that accounting disclosures have an information content that possesses value to stakeholders in providing useful signals.

It may be difficult or impossible for individual stakeholders to discern the fact and the effect of accounting manipulation, because of an insufficient personal skill set, indifference or an unwillingness to engage in detailed analysis (the mechanistic or naïve investor hypothesis, discussed by Breton and Taffler, 1995). From a market efficiency perspective such failures in understanding may not matter. Breton and Taffler point out in the conclusion to their study establishing that analysts' perception of creative accounting devices is somewhat deficient, only a small number of effective accounting experts may be required 'for the market as a whole appropriately to process window dressed numbers'. On the other hand, Healy and Wahlen (1999) cite studies that find that creative accounting prior to equity issues does affect share prices, suggesting that investors do not necessarily see through creative accounting. 
This paper is positioned within an informational perspective, tempered by the naïve investor hypothesis; it is based upon the propositions, firstly, that financial reporting does possess valuable information content, and secondly that distortions in it may not be readily discernible by all stakeholders or that their effects may not be truly appreciated.

There is a substantial literature on creative accounting, much of it originating in, and concerned with, the United States. However, the US literature offers valuable insights into creative accounting in any country with a reasonably highly developed capital market (a recent comprehensive review of the US literature is provided by Healy and Wahlen, 1999). Also, beyond the US, there has been a growth in the volume of literature discussing creative accounting issues.

The paper is structured as follows. First, we provide some definitions of creative accounting. Second, we analyse different motivations for its use and several creative accounting techniques. We continue by reporting various empirical studies that have sought to identify its existence, nature and incidence. The paper continues with a review of some ethical issues concerning creative accounting and concludes by suggesting possible solutions for this problem.

\section{Definitions of creative accounting}

Creative accounting is referred to also as income smoothing, earnings management, earnings smoothing, financial engineering and cosmetic accounting. The preferred term in the USA, and consequently in most of the literature on the subject is 'earnings management', but in Europe the preferred term is 'creative accounting' and so this is the term that will be used in this paper. It should be recognised that some accounting manipulation involves primarily balance sheet rather than earnings management. Definitions of creative accounting vary, and include the following:

'Is the deliberate dampening of fluctuations about "some level of earnings considered to be normal for the firm"”. (Barnea et al. 1976)

'Is any action on the part of management which affects reported income and which provides no true economic advantage to the organization and may in fact, in the long-term, be detrimental'. (Merchant and Rockness, 1994) 
'Involves the repetitive selection of accounting measurement or reporting rules in a particular pattern, the effect of which is to report a stream of income with a smaller variation from trend than would otherwise have appeared'. (Copeland, 1968)

Schipper (1989) observes that 'creative accounting' can be equated with 'disclosure management', 'in the sense of a purposeful intervention in the financial reporting process'.

In this paper we will consider that creative accounting involves a transformation of financial accounts using accounting choices, estimates and other practices allowed by accounting regulation.

\section{Motivation for creative accounting}

Various research studies have examined the issue of management motivation towards creative accounting behaviour. Half a century ago, Hepworth (1953) identified several motivations including the existence of tax levies based on income, confidence by shareholders and workers in management that is able to report stable earnings and psychological expectations relating to increases or decreases in anticipated income.

Tax is mentioned as a significant motivator also by Niskanen and Keloharju (2000) in a Finnish context and in Japan by Herrmann and Inoue (1996).

In countries with highly conservative accounting systems the 'income smoothing' effect can be particularly pronounced because of the high level of provisions that accumulate. Another bias that sometimes arises is called 'big bath' accounting, where a company making a bad loss seeks to maximise the reported loss in that year so that future years will appear better.

Beidleman (1973) observes the positive effects of income smoothing on expectations, seccurities valuation and some element of risk reduction for analysts. Other motivations for creative accounting discussed by Healy and Wahlen (1999) include those provided when significant capital market transactions are anticipated, and when there is a gap between the actual performance of the firm and analysts' expectations. A variant on income smoothing is to manipulate profit to tie in to forecasts. Fox (1997) reports on bw accounting policies in some companies are designed, within 
the normal accounting rules, to match reported earnings to profit forecasts. When these companies sell products a large part of the profit is deferred to future years to cover potential upgrade and customer support costs. This perfectly respectable, and highly conservative, accounting policy means that future earnings are easy to predict. Company directors may keep an income-boosting accounting policy change in hand to distract attention from unwelcome news. Collingwood (1991) reports on how a change in accounting method boosted a company's quarterly profit figure, by a happy coincidence distracting attention from the company slipping back from being the largest company in the industry in the USA to the number two slot.

Healy (1985) examines managers' earnings manipulations motives where executive compensation is linked to income measurement. Trueman and Titman (1988) discuss managers' motivations to reduce the perception of variability in underlying economic earnings of the firm. Kamin and Ronen (1978) observe a difference in motivation between managers in owner-controlled and management-controlled firms. Owners who wish to retain control of a sizeable stake and who are therefore not interested in immediate exit strategies are less likely to be motivated to manage earnings.

Creative accounting may help maintain or boost the share price both by reducing the apparent levels of borrowing, so making the company appear subject to less risk, and by creating the appearance of a good profit trend. This helps the company to raise capital from new share issues, offer their own shares in takeover bids, and resist takeover by other companies.

If the directors engage in 'insider dealing' in their company's shares they can use creative accounting to delay the release of information for the market, thereby enhancing their opportunity to benefit from inside knowledge.

It should be noted that, in an efficient market, analysts will not be fooled by cosmetic accounting charges. Indeed, the alert analyst will see income-boosting accounting changes as a possible indicator of weakness. Dharan and Lev (1993) report on a study showing poor share price performance in the years following income increasing accounting changes. Another set of reasons for creative accounting, which applies to all companies, arises because companlies are subject to various forms of contractual rights, obligations and constraints based on the amounts reported in the accounts.

\section{Techniques of creative accounting}


The potential for creative accounting is found in six principal areas: regulatory flexibility, a dearth of regulation, a scope for managerial judgement in respect of assumptions about the future, the timing of some transactions, the use of artificial transactions and finally the reclassification and presentation of financial numbers. Even in a highly regulated accounting environment such as the USA, a great deal of flexibility is available (Largay, 2002; Mulford and Comiskey, 2002). Taking each of the six areas in turn:

1. Regulatory flexibility. Accounting regulation often permits a choice of policy, for example, in respect of asset valuation (International Accounting Standards permit a choice between carrying non-current assets at either revalued amounts or depreciated historical cost). Business entities may, quite validly, change their accounting policies. As Schipper (1989) points out, such changes may be relatively easy to identify in the year of change, but are much less readily discernible thereafter.

2. Dearth of regulation. Some areas are simply not fully regulated. For example, there are (as yet) very few mandatory requirements in respect of accounting for stock options. In the majority of countries, like Spain for example, accounting regulation in some areas is limited: for example the recognition and measurement of pension liabilities and certain aspects of accounting for financial instruments.

3. Management has considerable scope for estimation in discretionary areas. McNichols and Wilson (1988), for example, examine the discretionary and nondiscretionary elements of the bad debts provision.

4. Genuine transactions can also be timed so as to give the desired impression in the accounts. As an example, suppose a business has an investment at historic cost which can easily be sold for a higher sales price, being the current value. The managers of the business are free to choose in which year they sell the investment and so increase the profit in the accounts.

5. Artificial transactions can be entered into both to manipulate balance sheet amounts and to move profits between accounting periods. This is achieved by entering into two or more related transactions with an obliging third party, normally a bank. For 
example, supposing an arrangement is made to sell an asset to a bank then lease that asset back for the rest of its useful life. The sale price under such a 'sale and leaseback' can be pitched above or below the current value of the asset, because the difference can be compensated for by increased or reduced rentals.

6. Reclassification and presentation of financial numbers are relatively under-explored in the literature. However, the study by Gramlich et al. (2001) suggests that firms may engage in balance sheet manipulation to reclassify liabilities in order to smooth reported liquidity and leverage ratios. A special type of creative accounting relates to the presentation of financial numbers, based on cognitive reference points. As explained by Niskanen and Keloharju (2000): 'the idea behind this behaviour is that humans may perceive a profit of, say, 301 million as abnormally larger than a profit of 298 million'. Their study and others (e.g. van Caneghem, 2002) have indicated that some minor massaging of figures does take place in order to reach significant reference points.

\section{Existence of creative accounting}

Even though managers' motivation for creative accounting may be established and accepted at least in theory, establishing empirically that it takes place is a separate problem.

Naser and Pendlebury (1992) questioned senior corporate auditors about their experience of creative accounting. They were able to conclude that a significant proportion of all categories of companies employ creative accounting techniques to some extent.

Many research studies examine a particular aspect or technique of creative accounting. All tend towards the conclusion that creative accounting using that particular technique does exist. McNichols and Wilson (1988) model the nondiscretionary component of the bad debts provision (so as to identify the discretionary element of the accrual). Barnea et al. (1976) discuss classificatory smoothing with the use of extraordinary items; their results, based on a study of 62 US companies, indicate that classificatory smoothing does take place. A later large scale study of classificatory smoothing (Dempsey et al., 1993) found that 'managers showed a propensity to report extraordinary gains on the income statement and extraordinary 
losses on the retained earnings statement'. Moreover, this research found that the propensity to report in this way was significantly greater in non-owner managed firms. Dascher and Malcom (1970) analysed data over several years for 52 firms in the chemical industries sector relating to four income smoothing variables: pensions costs, dividends from unconsolidated subsidiaries, extraordinary charges and credits and research and development costs. They concluded that their results were consistent with the hypothesis that deliberate smoothing had taken place. Large provisions against uncertain levels of future loss are highly dependent upon the judgements made by management. Healy and Wahlen (1999) cite several studies that find 'compelling evidence' of income smoothing via accruals in banks and insurers, for example, Beatty et al. (1995).

Merchant (1990) examines management manipulation of accounting information within two firms (i.e. information used in internal reporting by divisions) drawing upon both interview and questionnaire data. The research found that 'managers acknowledged manipulative behaviours and short-term orientations'.

Black et al. (1998) examine non-current asset sales as creative accounting tools, using a very large dataset of observations from Australia, New Zealand and the UK. They find that, where the relevant accounting standards are permissive (as in the UK up till 1993) managers will exploit the potential for creative accounting via timing of asset sales. Such behaviours are curtailed once the provisions of accounting standards are tightened. However, amongst their conclusions, they observe that 'there is every reason to believe that firms can "shift" creative accounting activity among a variety of methods'. So, even if certain loopholes in regulation are eliminated, creative accounting behaviour is likely to persist.

Amat et al (2003) report about a study that identified creative accounting practices in some of the 35 large Spanish listed companies. It should be noted that, therefore, any creative accounting behaviour identified in the study was relatively overt, and almost certainly legal. The following occurrences were classified for the purposes of this study as possible indicators of creative accounting:

-Auditor report qualifications (in Spain there is no requirement to restate the financial statements to reflect the effect of the qualifications. The effect is, however, noted in the audit report).

-Special authorisations from regulatory agencies to adopt non-standard policy. 
-Changes in accounting policy from one year to another (in Spain, such changes have to be explained and the consequences quantified in the auditor's report).

In this study, the impact of creative accounting on reported earnings was assessed for each of the three financial years in the 1999-2001 period. The aggregate impact on earnings of creating accounting practices amounted $20 \%$ of total reported earnings. The number of companies which managed earnings are summarized in Table 1. A company was supossed to manage its earnings when reported earnings were different from adjusted earnings (adjusted for creating accounting practices).

\begin{tabular}{|l|r|r|r|}
\hline & 1999 & 2000 & 2001 \\
\hline \% of companies that managed earnings & $40 \%$ & $45,7 \%$ & $25,7 \%$ \\
\hline Number of companies & 14 & 16 & 9 \\
\hline Reported earnings > Adjusted earnings & 5 & 11 & 7 \\
\hline Reported earnings < Adjusted earnings & 9 & 5 & 2 \\
\hline
\end{tabular}

Source: Amat et al (2003)

Table 1. Number of Spanish larger listed companies (out of 35) that managed earnings during the period 1999-2001.

It may be noted that in 1999, a year when the economy was in a relatively buoyant condition, the reported earnings of 9 firms were less than adjusted earnings. However, in 2000 and 2001 when the Spanish economy was affected by an economic downturn, the position is reversed. A clear majority of the companies under scrutiny in both years showed reported earnings higher than adjusted earnings. The results of the study over a three year time period suggest that the direction of creative accounting could be related to general economic conditions. (This possibility was flagged by Merchant (1990)).

However, there are some unusual features of the Spanish accounting environment that merit special attention. First, audit report qualifications are common, even in respect of major listed companies (Acerete Gil et al, 2002, find that between in the years 1996-2000 the number of qualified audit opinions in the financial statements of listed Spanish companies fell but the number was still high in 2000 when 92 companies had audit qualifications). Second, a feature which is likely to elicit some surprise outside Spain, an element of creative accounting may be carried out with the collusion of the regulatory authorities. Supervising agencies may permit individual companies to adopt an accounting policy which contravenes current accounting regulation. Such 
authorisations are provided as a result of effective lobbying by either a company or representative companies within an industrial sector. Successful lobbying of this type demonstrates the power of influence that the business sector may have over government or its agencies. The practice of charging expenses to reserves rather than to the income statement may also be permitted.

All of the creative accounting behaviours identified in this study were identified through careful analysis of the financial statements. Some of the manifestations were easier to identify than others, but all should be observable by a reasonably wellinformed user of the financial statements. The question may be asked: if the creative accounting behaviour is so obvious, can it properly be classified as creative accounting at all? However, the extent to which users of the statements actually do observe such relatively clear examples of creative accounting is uncertain. It has been observed that analysts' reports in Spain usually fail to mention the existence of audit report qualifications, special authorisations or other manifestations of creative accounting practices. Even quite clear signalling can be misinterpreted or ignored even by relatively sophisticated users (Breton and Taffler, 1995). Furthermore, Dechow and Skinner (2000) argue that even if financial statements provide sufficient information to permit users to adjust for creative accounting, there would still be cause for concern over the value of the information content because of "the possibility that certain investors rely completely on earnings numbers reported on the face of the income statement because their ability to process more sophisticated (i.e. footnote) information is limited'.

The results of these researchs show that some elements of overt creative accounting practices are common.

\section{The ethical perspective}

Companies generally prefer to report a steady trend of growth in profit rather than to show volatile profits with a series of dramatic rises and falls. This is achieved by making unnecessarily high provisions for liabilities and against asset values in good years so that these provisions can be reduced, thereby improving reported profits, in bad years. Advocates of this approach argue that it is a measure against the shorttermism' of judging an investment on the basis of the yields achieved in the immediate following years. It also avoids raising expectations so high in good years 
that the company is unable to deliver what is required subsequently. Against this is argued that if the trading conditions of a business are in fact volatile then investors have a right to know this and that income smoothing may conceal long-term changes in the profit trend.

Revsine (1991) considers the problem in relation to both managers and shareholders and argues that each can draw benefits from 'loose' accounting standards that provide managers with latitude in timing the reporting of income. He thinks that the prime role of accounting is as a mechanism for monitoring contracts between managers and other groups providing finance; market mechanisms will operate efficiently, identifying the prospect of accounting manipulation and reflecting this appropriately in pricing and contracting decisions.

The literature on the ethics of bias in accounting policy choice is reviewed at the 'macro' level of the accounting regulator. This literature can similarly be applied to the bias in accounting policy choice at the 'micro' level of the management of individual companies that is implicit in creative accounting. If we consider the position taken by Ruland (1984) and compare it to Revsine's analysis, we note that Ruland distinguishes between the deontological view whereby moral rules apply to actual actions and the teleological view that an action should be judged on the basis of the moral worth of the outcome. Revsine appears to take a teleological view of accounting in the private sector, allowing managers to choose between the alternatives permitted in 'loose' standards to achieve their desired end, but to take a deontological view of accounting in the public sector where he calls for tighter standards to prevent such manipulation. We might ask whether the presence or absence of market discipline justifies such ethical inconsistency. Ruland also discusses the distinction between a 'positive' responsibility, which here would be the duty to present unbiased accounts, and a 'negative' responsibility where managers would be responsible for states of affairs they fail to prevent. As we have seen, Ruland gives priority to the 'positive'. Within Revsine's framework, where all outcomes are deemed to be impounded in the process of contracting and price-setting, the distinction is not acknowledged. The 'duty to refrain' would imply avoiding the bias inherent in creative accounting while the 'duty to act' would involve pursuing the consequences to be achieved by creative accounting. If we take the three issues where Ruland sees the 'duty to refrain' as the more important: 
(a) Relentlessness and

(b) Certainty of outcome: Revsine's arguments, as we have seen, apply to a limited role for accounting as a primarily contract monitoring exercise.

(c) Responsibility: Revsine seems to see compliance with GAAP as the prime responsibility, with no constraint on choice within GAAP. This may be a legitimate approach in the USA, but in a jurisdiction that prescribes an overriding qualitative objective for accounts, such as the European Union with 'true and fair view', Revsine's approach is less defensible.

To the professional accountant creative accounting generally seems to be regarded as ethically dubious. In the USA the then senior partner of Price Waterhouse observed: "When fraudulent reporting occurs, it frequently is perpetrated at levels of management above those for which internal control systems are designed to be effective. It often involves using the financial statements to create an illusion that the entity is healthier and more prosperous than it actually is. This illusion sometimes is accomplished by masking economic realities through intentional misapplication of accounting principles.” (Conner 1986: 78)

In Australia Leung and Cooper (1995) found that in a survey of 1500 accountants the three ethical problems cited most frequently were conflict of interest, client proposals to manipulate accounts and client proposals for tax evasion.

Two surveys of attitudes to creative accounting in the USA both highlight a difference in accountants' attitudes to creative accounting depending on whether it arises from abuse of accounting rules or from the manipulation of transactions. Fischer and Rosenzweig (1995) found that accounting and MBA students were more critical than accounting practitioners of manipulated transactions, whereas accounting practitioners were more critical than students of abuse of accounting rules.

Merchant and Rockness (1994) similarly found that, when presented with scenarios of creative accounting, accountants were more critical of abuse of accounting rules than of manipulation of transactions. Fischer and Rosenzweig offer two possible explanations for accountants' attitudes. First, accountants may take a rule-based approach to ethics, rather on the impact on users of the accounts. Second, accountants may see abuse of accounting rules as falling within their domain, and therefore demanding their ethical judgement, while the manipulation of transactions falls within the domain of management and so is not subject to the same ethical code. Merchant 
and Rockness also found a difference in accountants' attitudes to creative accounting depending on the motivation of management. Creative accounting based on explicit motives of self-interest attracted more disapproval than where the motivation was to promote the company.

An accountant, or other manager, who takes a stand against creative accounting faces the same pressures as any other whistleblower. In extreme cases failure to act could ruin a reputation. As one company accountant who took a firm stand put it: 'It cost me my job, but I don't think I would have gotten another job had I been unethical' (quoted by Baldo 1995).

Schilit (1997) reports the case of one company accountant confronted with such an issue. His employer; a food wholesaler, incurred substantial costs in paying retailers to put new lines on their shelves. This is a common practice, known as 'slotting', and the costs are commonly written off in the year they are incurred. In order to keep within accounting ratios under loan agreements the company president proposed to capitalise the slotting costs and amortise them over ten years. The accountant undertook some research on other company practices, and as a result was confirmed in the view that this was not an acceptable accounting treatment. After, he identified cost savings that would have just kept the company inside its loan agreement and alerted the auditors to the issue, hoping 'that they would play the role of bad cop and force the company to expense the 'slotting'.

The principal investor in the company tried, unsuccessfully, to put pressure on the auditor to support the capitalisation of the slotting costs. Shortly after the accountant was sacked for taking this stand. The series of actions in this case are revealing:

-Check that the proposed accounting method is in fact unacceptable. As Hamilton (1991) advises: First, try to verify your suspicions about what you think is wrong. Some accounting practices that are legal under new laws may look suspect to a non accountant. If you blow the whistle on something that's not illegal, you're really bare and perhaps even vulnerable to defamation claims.

-Search for alternative legitimate ways to achieve the desired end and offer these as an alternative approach to management.

-In the last resort, report the abuse to the appropriate monitor. 


\section{Are there solutions?}

It seems clear that in general creative accounting is seen as a deceitful and undesirable practice. In this section we analyse some measures which can help to reduce the scope for creative accounting practices, identifying, where applicable, recent developments in International Accounting Standards (IASs). IASs will become the standard for all European listed companies from 2005.

Accounting regulators who wish to curb creative accounting have to tackle each of these approaches in a different way:

1. Scope for choice of accounting methods can be reduced by reducing the number of permitted accounting methods or by specifying circumstances in which each method should be used. Requiring consistency of use of methods also helps here, since a company choosing a method which produces the desired picture in one year will then be forced to use the same method in future circumstances where the result may be less favourable. The latest developments in International Accounting Standards are pursuing the objective of reduction in accounting choice. (IASB, 2003).

2. Abuse of judgement can be curbed in two ways. One is to draft rules that minimise the use of judgement. At one time, for example, company accountants tended to use the 'extraordinary item' part of the profit and loss account for items they wished to avoid including in operating profit. Again, the present rules of the International Accounting Standards have nearly abolished the category of 'extraordinary item'. Auditors also have a part to play in identifying dishonest estimates. The other is to prescribe 'consistency' so that if a company chooses an accounting policy that suits it in one year it must continue to apply it in subsequent years when it may not suit so well.

3. Artificial transactions can be tackled by invoking the concept of 'substance over form', whereby the economic substance rather than the legal form of transactions determines their accounting substance. Thus linked transactions would be accounted for as one whole.

4. The timing of genuine transactions is clearly a matter for the discretion of 
management. However, the scope to use this can be limited by requiring regular revaluations of items in the accounts so that gains or losses on value changes are identified in the accounts each year as they occur, rather than only appearing in total in the year that a disposal occurs. It is interesting to observe that the International Accounting Standards Board is tending to move towards valuation at fair value rather than based upon historical cost in several recent accounting standards and discussion papers.

But apart from changes in accounting regulation, ethical standards and governance codes must be properly enforced in the corporate world. Regulation without thorough enforcement techniques is likely to be ineffective in preventing individuals from employing misleading reporting practices. The challenge of enforcing Internacional Accounting Standards within a range of differing accounting cultural contexts is likely to be especially problematic.

\section{References}

Acerete Gil, J.B, Fuertes Callén, Y. and Pascual Gaspar, E.: 2002 'Las salvedades en auditoria: el caso de empresas cotizadas en España', Partida Doble, N. 135, JulyAugust, pp. 60-65.

Amat, O., Gowthorpe, C. and Perramon, J.: 2003 'Earnings management in Spain: an assessment of the effect on reported earnings of larger listed companies 1999-2001', Economic Working Paper Series, Universitat Pompeu Fabra.

Baldo, A.: 1995 'What's right? What's wrong?', Treasury and Risk Management, November.

Barnea, A., Ronen, J. and Sadan, S.: 1976 'Classificatory smoothing of income with extraordinary items', The Accounting Review, January, pp.110-122.

Beatty, A., Chamberlain, S.L. and Magliolo, J.: 1995 'Managing financial reports of commercial banks: the influence of taxes, regulatory capital and earnings', Journal of Accounting Research, Vol. 33, No. 2, pp. 231-61.

Beidleman, C. R.: 1973 'Income smoothing: the role of management', The Accounting Review, October, Vol. XLVIII, pp. 653-667.

Black, E.L., Sellers, K.F. and Manly, T.S.: 1998 'Creative accounting using asset sales: an international study of countries allowing noncurrent asset revaluation', 
Journal of Business Finance and Accounting, 25(9) \& (10), November/December, pp.1287-1317.

Breton, G. and Taffler, R.J.: 1995 'Creative accounting and investment analyst response', Accounting and Business Research, Vol. 25, No. 98, pp. 81-92.

Collingwood, H.: 1991 'Why K-Mart's good news isn't', Rusiness Week, March, 18, p.40.

Conner, I.E.: 1986 'Enhancing public confidence in the accounting profession', Journal of Accountancy, July, p.7683.

Copeland, R.M.: 1968 'Income smoothing', Journal of Accounting Research, VVI, Supplement, pp.101-116.

Dascher, P.E. and Malcom, R.E.: 1970 'A note on income smoothing in the chemical industry', Journal of Accounting Research, Autumn, pp. 253-259.

Dechow, P.M. and Skinner, D.J.: 2000 'Creative accounting: reconciling the views of accounting academics, practitioners and regulators', Accounting Horizons, Vol. 14, Issue 2, pp. 235-51.

Dempsey, S.J., Hunt, H.G. and Schroeder, N.W.: 1993 'Creative accounting and corporate ownership structure: an examination of extraordinary item reporting', Journal of Business Finance and Accounting, 20(4), June, pp. 479-500.

Dharan, B. and Lev, B.: 1993 'The valuation consequence of accounting charges: a multi- year examination', Journal of Accounting Auditing and Finance, 8 (4), pp 47594.

Fischer, M. and Rosenzweig. K.: 1995 'Attitudes of students and accounting practitioners concerning the ethical acceptability of creative accounting', Journal of Business Ethics, 14, pp. 433-44.

Fox, J.: 1997 'Learn to play the Earnings Game', Fortune, 31 July.

Gramlich, J.D., McAnally, M.L. and Thomas, J.: 2001 'Balance sheet management: the case of short-term obligations reclassified as long-term debt', Journal of Accounting Research, Vol. 39, No. 2, pp. 283-95.

Hamilton, J.: 1991 'Blowing the whistle without paying the piper', Business Week, 3 June, p.138.

Healy, P.M.: 1985 'The effect of bonus schemes on accounting decisions', Journal of Accounting and Economics, 7, pp. 85-107. 
Healy, P.M. and Wahlen, J.M.: 1999 'A review of the creative accounting literature and its implications for standard setting', Accounting Horizons, Vol. 13, No. 4, pp. 365-83.

Hepworth, S.R.: 1953 'Smoothing periodic income', The Accounting Review, January: pp. 32-39.

Hermann, D. and Inoue, T.: 1996 'Income smoothing and incentives by operating condition: an empirical test using depreciation changes in Japan', Journal of International Accounting Auditing and Taxation, Vol. 5, Issue 2, pp.161-78.

Horrigan, J.O.: 1987 'The ethics of the new finance', Journal of Business Ethics, 6, pp.97-110.

IASB: 2003 'International Accounting Standards'. London: IASB.

Jensen, M.C. and Meckling, W.H.: 1976 'Theory of the firm: managerial behaviour, agency costs and ownership structure', Journal of Financial Economics, 3, pp.306360.

Kamin, J.Y. and Ronen, J.: 1978 'The smoothing of income numbers: some empirical evidence on systematic differences among management-controlled and ownercontrolled firms', Accounting, Organizations and Society, Vol. 3, No. 2, pp.141-57.

Largay, J.: 2002 'Lessons from Enron', Accounting Horizons, Vol. 16, No. 2, p.154

Leung, F and Cooper, B.: 1995 'Ethical dilemmas in accountancy practice', Australian Accountant, May, pp.28-33.

McNichols, M. and Wilson, G.P.: 1988 'Evidence of creative accounting from the provision for bad debts', Journal of Accounting Research, Vol. 26, Supplement, pp.133.

Merchant, K.A.: 1990 'The effects of financial controls on data manipulation and management myopia', Accounting, Organizations and Society, Vol. 15, No. 4, pp. 297-313.

Merchant, K.A. and Rockness, J.: 1994 'The ethics of managing earnings: an empirical investigation', Journal of Accounting and Public Policy, 13, pp.79-94.

Mulford, C.W. and Comiskey, E.E.: 2002 The financial numbers game: detecting creative accounting practices. New York: Wiley.

Naser, K. and Pendlebury, M.: 1992 'A note on the use of creative accounting', British Accounting Review, 24, pp.111-118. 
Niskanen, J. and Keloharju, M.: 2000 'Earning cosmetics in a tax-driven accounting environment: evidence from Finnish public firms', The European Accounting Review, Vol. 9:3, pp. 443-452.

Rahman, A.R. and Penera, M,H.B.: 1997 Accounting and its environment in New Zealand', in N. Baydoun, A. Nishimura, and R. Willet, Accounting in the Asia-Pacific Region, Singapore: John Wiley (Asia), pp.127-157.

Revsine, L: 1991 'The selective financial misrepresentation hypothesis', Accounting Horizons, December, pp.16-27.

Ruland, R.G.: 1984 'Duty, obligation and responsibility in accounting policy making', Journal of Accounting and Public Policy, Fall, pp.223-37.

Schilit, H.M.: 1997 'Is it fraud or just slick accounting?', CEO Magazine, August.

Schipper, K.: 1989 'Commentary on creative accounting', Accounting Horizons, December, pp. 91-102.

Trueman, B. and Titman, S.: 1988 'An explanation for accounting income smoothing', Journal of Accounting Research, Vol. 26, Supplement, pp.127-139.

van Caneghem, T.: 2002 'Creative accounting induced by cognitive reference points', British Accounting Review, 34, pp.167-78. 